\title{
Research on the Development of Tourism under the Background of Cooperative Development of Beijing-Tianjin-Qinhuangdao Metropolitan Region
}

\author{
Qian Xia, Haicheng Zhang \\ Qinhuangdao Institute of Technology, Qinhuangdao, Hebei, China
}

\begin{abstract}
Beijing, Tianjin and Qinhuangdao are located in the Bohai Rim of China. They are the most important tourism markets within Beijing-Tianjin-Hebei metropolitan region. Superior geographical position, rich tourism resources and strong complementarity create good conditions for the cooperative development of Beijing-Tianjin-Hebei Metropolitan Region. Based on the hot topic of cooperative development of Beijing-Tianjin-Hebei, this paper chooses Beijing, Tianjin and Qinhuangdao as the breakthrough points. It combines the tourism characteristics of the three regions, compares the other two metropolitan areas and analyzes the factors restricting the interaction of its tourism development. In addition, it uses successful experience of the tourism development of the Yangtze Delta area for reference, which opens up a new model for the tourism development of Beijing-Tianjin-Hebei metropolitan region.
\end{abstract}

Keywords - cooperative development of Beijing-Tianjin-Qinhuangdao, Metropolitan Region, tourism development

\section{京津秦协同发展背景下的都市圈旅游发展研究}

\author{
夏倩 张海成 \\ 秦皇岛职业技术学院，秦皇岛，河北，中国
}

摘 要 北京、天津和秦皇岛位于中国的环渤海地区, 是京津冀都市圈内最重要的三大旅游市场。地理位置优越、旅游资源丰富、 互补性强, 为实现京津冀大都市圈的联动发展创造了良好条件。本文基于京津冀协同发展这一热点话题, 选取了京、津、秦三个城市 为切入点, 结合了三地的旅游特色, 与另外两大都市圈进行对比分析, 分析了自身旅游业互动发展的制约因素, 借鉴了长三角地区旅 游业联动发展的成功经验, 从而开辟了京津冀环渤海大都市圈旅游业发展的新模式。

关键词＼cjkstart京津秦协同发展, 都市圈, 旅游发展

\section{1. 引言}

区域旅游合作是近年来世界旅游业发展的一大趋势。 不同的区域, 其内部的要素构成、结构、功能都不尽相同, 因而区域之间开展旅游合作的模式也有所差别。目前, 我 国区域旅游合作已经形成了“长三角”、“珠三角”、“京津冀” 三大都市圈的三足鼎立局面, 但是旅游合作的进程却不尽 相同。“长三角”和“珠三角”地区旅游合作的速度已经远远 超过了京津冀地区，并且各自形成了一套适合自己区域的 旅游合作模式。

北京、天津和秦皇岛位于中国的环渤海地区, 是京津 冀都市圈内最重要的三大旅游市场。地理位置优越、旅游
资源丰富、互补性强, 为实现京津冀大都市圈的联动发展 创造了良好条件。

\section{2. 京津秦都市圈旅游发展现状}

\section{1 京津秦旅游资源分布现状}

京津冀都市圈旅游资源极其丰富, 自然旅游资源品种 繁多、形态各异, 是全国唯一兼有海洋、平原、草原、丘 陵、山地、高原的区域; 旅游资源丰富, 皇家文化旅游资 源、农业旅游资源、都市文化旅游资源等相互交融, 有利 于构成相互补充的旅游线路和旅游产品。 
作为京津冀都市圈中最有影响力的三个城市, 北京、 天津和秦皇岛各有特色, 且互补性强。其中拥有三千年历 史的古都北京发挥其国家首都的独特作用, 作为中国政治、 文化和经济中心，一直以来都是国内外游客的首选。而有 着六百年历史的国家历史文化名城天津，在保护历史风貌 建筑、尽显原有特色、延续城市文化、提升旅游价值方面 厚积薄发, 是地域文化特色、中国近代史以及现代化都市 的缩影。与京津相比, 秦皇岛拥有山、海、关等各种旅游 资源, 搭配合理, 是华北地区最适合度假的地方。京津冀 一体化在全国来看, 秦皇岛不仅仅是北京周边的一个旅游 点、后花园, 而是通往关外的一个重要节点。

\section{2 京津秦旅游协同发展现状}

从2004年国家开始着手编制区域以后, “京津冀都市 圈”一词才得到各界的广泛运用, 但早在1985年京津冀地 区就开始了相关区域旅游合作的探索, 至今已有近30年的 历程, 成为继 80 年代的珠江三角洲、长江三角洲之后的中 国第三经济增长极。位于环渤海地区中心地带的京津秦三 地被称为第三经济增长极的核心引擎。

从京东旅游区、北方旅游交易会, 到环渤海区域经济 合作联席会议、京津冀旅游宣传周; 从《首都都市度假旅 游圈规划》到京津冀——港澳台 $(3+3)$ 旅游合作大会、 环渤海港口城市旅游合作组织; 从京津冀旅游合作会议、 奥运旅游行动合作计划到《京津冀旅游合作协议》、京津冀 旅游合作恳谈会, 圈内各旅游城市之间既存在合作, 同时 也出现同构、无序竞争等现象。

\section{3. 京津秦旅游业协同发展的制约因素分析}

\section{1 不同的行政区划对京津秦旅游业发展的制约}

“行政区经济现象”，作为我国区域经济的特殊表现形 式，在区域旅游协同发展中也有着不同程度的影响。京津 秦地区虽然地域上紧密相连，却分属三个不同的行政区域。 长期以来, 各行政区在发展旅游经济时往往只从地方利益 的角度出发, 各自为政。各地政府没有充分意识到区域旅 游合作的意义, 没有形成互惠互利的观念。以地方利益为 前提的政策导向使雷同的旅游项目在区域内盲目重复建 设，造成旅游资源和建设资金的严重浪费。

\section{2 三地旅游业发展不平衡的制约}

从理论上讲, 区域旅游不平衡的合作基础也正奠定了 互补合作的前提条件，促使行政区间努力寻找发展的契机， 相互取长补短, 实现共盈发展。但由于分属三个不同的行
政区，使旅游业发达的北京不愿意与落后的河北旅游进行 合作, 因为这种合作在短期内难以看到效果, 各地区旅游 业发展的不均衡性在长期内还将阻碍合作的进程。

\section{3 旅游合作系统有待于进一步完善}

首先, 从道路交通来看, 京津秦三地虽然有多条高速 公路贯穿, 但存在关卡林立, 互设障碍的现象, 提高了三 地间旅游的成本。其次, 尽管从北京到秦皇岛的公路交通 时间一般在两至四个小时之间, 但拨打手机却要支付高昂 的漫游费。此外, 旅游景区周边的环保、绿化等都会对旅 游景区产生影响。最后, 旅游合作信息建设较为滞后, 笔 者搜索了京津秦三地旅游局的网站, 关于三地旅游合作的 内容殄胗无几。

\section{4. 京津秦旅游业协同发展的实现路径}

\section{1 打破行政区划的束缚, 编制区域旅游发展总体规划}

2014年5月10日，由秦皇岛市旅游局组织、策划的“秦 皇岛旅游产业对接京津冀协同发展战略研讨会”在北戴河 举行。三地旅游局负责人共同宣布, 京津冀将建立区域旅 游协作会议制度; 策划设计共同的旅游宣传口号, 统一发 布使用; 联合开发三地的若干条精品旅游线路或旅游产品。 同时, 京津冀旅游部门将共同建立联动机制, 完善救援应 急机制, 对旅游市场进行规范整顿。以两市一省目前的旅 游质监投诉电话为基础, 建立三方旅游投诉和应急事件处 理热线电话, 确保节假日24小时开通。但我们看到, 这种 旅游合作协议还更多地停留在倡议和个别问题的层面上, 我们期待以该协议为契机, 三地旅游部门联合编制区域旅 游发展总体规划, 加大对京津秦世界文化遗产的整体宣传 促销, 尤其是对北京和北京以外的世界遗产的整体宣传, 进行京津秦世界遗产精品游系列的线路策划与组织, 扩大 京津秦旅游业的知名度; 构建统一的区域旅游网络营销系 统和旅游电子商务服务平台, 加强三地的自然旅游和红色 旅游的开发宣传。

\section{2 笁选特色互补旅游资源, 打造精品线路}

京、津、秦三地都拥有丰富的旅游资源, 且三地的城 市旅游特色各不相同, 但三地同属华北地区, 在某些资源 方面有近似之处。作为联合发展的旅游线路, 同一景点不 应在一条线路中重复出现, 笁选特色鲜明且三地互补的旅 游资源就成为了打造“京津秦”线路旅游的重点。秦皇岛以 山海等自然景观为特色, 同时拥有天下第一关、老龙头、 孟姜女庙等人文景观, 还拥有南戴河国际娱乐中心、北戴 河观鸟胜地等休闲娱乐处所, 更拥有亚洲最大酒㝨、全国 
最大能源输出港等工业景观, 这与以历史人文、科技著称 的北京和以民俗文化、现代工业著称的天津形成了多种旅 游资源的互补。秦皇岛的各种旅游资源都能够与北京、天 津的城市旅游特色完美融合, 形成既具有地区特色又不失 线路整体风格的城际区域游。通过京津秦区域联合, 打造 集文化内涵、自然景观、休闲娱乐、民俗特色于一体的跨 区域旅游线路, 能够大幅提升旅游线路广度以及城市间的 互动合作, 以精品线路拉动区域旅游的全面启动。

\section{3 加快京津秦旅游环境建设, 保证旅游通道的建设}

2007 年 4 月火车第六次大提速和 $\mathrm{D}$ 字头动车组的出 现, 一小时直通京津, 三小时直通京津冀已成为现实。同 时, 交通铁路也将与航空、公路交通融为一体, 使京津秦 的交通更加便利、快捷。在此基础上, 是否考虑首先在京 津秦三个行政区域内最紧密的范围内, 撤销公路分散收费 的关卡, 使公路交通更加通畅, 同时加强主要旅游景区的 直通旅游交通建设。

三地旅游局的网站可否专门开设一个京津秦旅游合作 发展栏目, 建立一个互相交流信息的平台。在京津秦范围 内可否设立旅游信息中心, 相互为到访的或潜在的旅游者 提供整个区域的旅游信息, 甚至做到联合提供旅游服务设 施的预订。如果有可能的话在京津秦的范围内取消旅游企 业经营的属地限制、三个行政区联合颁发一定数量的导游 证, 导游人员可以自由受聘于各个旅行社而不受行政区划 限制。同时, 旅游部门也要和环保、绿化、通讯等部门相 互沟通, 共同为旅游业创造一个良好的外部环境。总而言 之, 要从拆除制约整个区域内旅游发展的障碍入手, 为旅 游长期发展的合作“搭桥铺路”, 这是非常重要的, 也是最 基础的。

\section{4 旅游资源深入开发，促成“三地”旅游一体化格局}

“京津秦”旅游品牌逐步形成之后, 将会是一个涵盖众多 主题旅游与特色旅游线路的旅游概念, 超越单一的地理串 联水平, 达到以主题内涵为主线串联的跨区域联盟合作。
对于线路周边辐射范围内的旅游资源, 可以选择符合“京津 秦”旅游品牌内涵的景点逐步扩充品牌所属线路, 扩充战略 联盟的辐射范围及旅游资源。打破地域局限, 以旅游主题 为核心, 扩充品牌辐射范围及品牌内容, 进而为其增加新 的活力、扩大市场。由此, 可通过吸纳承德避暑山庄、遵 化清东陵等周边景点将 “京津秦”旅游品牌逐步扩充成为 “京津冀”旅游战略联盟, 将跨区域旅游提升到一个新的高 度。

区域间的旅游合作打破了传统的地域观念, 主题旅游、 特色旅游等更加具有人文内涵、更有个性的旅游线路成为 了旅游消费市场的又一强劲动力, 同时赋予了传统景区新 的发展契机, 打造旅游品牌俨然已经成为了开发旅游市场 的一把利剑。京津秦三地优越的区位条件以及特色鲜明的 旅游资源为其跨区域合作发展提供了良好的基础。

\section{5. 致谢}

本文系 2014 年秦皇岛市级科技计划项目(第一批) “京 津秦协同发展背景下的都市圈旅游发展研究” (项目编号: 201401A309)的研究成果

\section{参考文献(References)}

[1] KimBeason, "Interorganizational relations in tourism," Annals of Tourism Research,1991

[2] Ritcheal, "Tourism destination competitiveness and societal prosperity," Journal of Business Research, 1999

[3] Yaming Zhang, Wenwen Zhang, "The Regional Tourism Economic System Dynamics of Beijing-Tianjin-Hebei," Management Journal,2005

[4] Jifu Zhang, Hui Zhang, "Bottleneck of Beijing Tianjin Hebei Economic Integration And Development Path," Economic Research Reference,2005

[5] Maohua Tang," "Outlook And Prospects of Development Strategy of Beijing Tianjin Hebei Regional Economic Integration," Journal of Hebei University of Economics and Business, 2005 